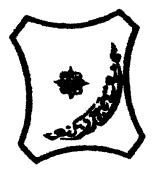

Bayero Journal of Pure and Applied Sciences, 8(1): 115 - 122

Received: February, 2015

Accepted: June, 2015

ISSN $2006-6996$

\title{
EFFECT OF DIFFERENT HEAT PROCESSING METHODS ON THE PROXIMATE COMPOSITION OF PILIOSTEGMA RETICULATUM SEED MEAL
}

\author{
${ }^{1}$ Musa Haruna, and ${ }^{2}$ A.H. Bichi \\ ${ }^{1}$ Department of Biology, Kano State University of Science and Technology, Wudil, \\ ${ }^{2}$ Department of Fisheries and Aqua-cultural Technology, Federal University Dutsin-ma, Katsina.
}

\section{ABSTRACT'}

Plants (legumes) are important sources of dietary protein for both human and animals, but the presence of antinutritive factors affect the nutritional quality of the legumes. Unless these factors are destroyed by processing methods, they can exert adverse physiological effects when ingested by animals. To improve the nutritional quality of legumes for animal feed, it is important to establish a processing method that will remove or reduce these antinutritive factors The objectives of this study is to determine the processing method suitable for processing $P$. reticulatum seed for animal feed formulation. The proximate composition of the raw and differently heat processed $P$. reticulatum seed were investigated using Association of Officials Analytical Chemists (AOAC, 1990). Complete randomized experimental design with triplicates replications was applied. The raw seed revealed the following result moisture $(7.27 \%)$, crude protein $(34.20 \%)$, crude fire (6.05\%), ether extract $(5.51 \%)$, ash (7.21\%), nitrogen free extract (47.03); the result of 30 minutes boiled seed was moisture $(7.26 \%)$, crude protein $(36.01 \%)$, crude fibre $(4.71 \%)$, ether extracts (7.10\%), ash (8.09\%) and nitrogen free extracts (44.08\%); 60 minutes boiled seed indicated the following results moisture $(6.25 \%)$, crude protein $(31.54 \%)$, crude fibre $(3.33 \%)$, ether extract (8.22\%), ash (14.01\%) and nitrogen free extract (42.90\%); traditionally boiled seed results were moisture $(7.07 \%)$, crude protein $(28.48 \%)$, crude fibre $(3.07 \%)$, ether extracts $(12.89 \%)$, ash (11.76\%) and nitrogen free extracts (43.78\%); 40 minutes toasted seed results were moisture $(1.91 \%)$, crude protein $(31.94 \%)$, crude fibre $(5.29 \%)$, ether extracts $(11.21 \%)$, ash (13.02\%) and nitrogen free extracts (38.62\%); The results of 80 minutes toasted seed were moisture $(5.16 \%)$, crude protein $(20.96 \%)$, crude fibre $(5.24 \%)$, ether extracts $(9.04 \%)$, ash $(8.74 \%)$ and nitrogen free extracts (55.69\%); 120 minutes toasted seed results were: moisture $(10.24 \%)$, crude protein $(24.12 \%)$, crude fibre $(3.42 \%)$, ether extracts $(9.03 \%)$, ash $(11.27 \%)$ and nitrogen free extracts (52.16\%) and the traditionally roasted seed record the following results moisture $(3.20 \%)$, crude protein $(31.37 \%)$, crude fibre $(2.60 \%)$, ether extracts $(8.15 \%)$, ash $(12.91 \%)$ and nitrogen free extracts (44.20\%). In the proximate analysis, T2 (30 minutes boiled seed) had the highest crude protein content (36.01\%), disadvantaged when compared with T3 (60 minutes boiled seed), T5 (40 minutes toasted seed) and T8 (traditionally roasted seed) in the other parameters. Among these treatments (T3, T5 and T8), T3 has an advantage over the others in terms of moderate crude protein (CP) and nitrogen free extract and also had the highest ash content. T1 (raw seed), although has high (34.20\%), but recorded the highest crude fiblre and the lowest ash content. Thus from this finding of this study, T3 appeared to be the best in terms of proximate composition for animal feed formulation.

Keyword : Piliostigma reticulatum, seed, heat processing, proximate composition.

\section{INTRODUCTION}

Covering the gap between the teaming population and food production is one of the most important tasks of developing countries. Most developing tropical countries have depended on major conventional legumes and animal based sources as key protein concentrates for livestock feeding as well as for human nutrition. The major conventional legumes are soybean (Glycine max) and ground nut or peanut (Arachis hypogea). The demand for these items has given rise to an increase in their prices and consequently to the cost of livestock and feeds. Protein -Energy Malnutrition (PEM) has therefore been recognized as the most common form of malnutrition in regions where people depend on starch based diets for survival (FAO, 1994; Pellelier, 1994; Michaelson and Henrik, 1998) .There is therefore, the need for identification and exploitation of other legumes which are in abundance and inexpensive than the conventional source of plant protein. Piliostigma reticulatum is among these abundant plants. The family Caesalpiniaceae, to which $P$. reticulatum belongs consists of about 200 species of 58 genera in tropical Africa. The caesalpiniaceae species are usually trees or shrubs, and rarely herbs or vines. The leaves are often large and brightly coloured. The fruits are usually pods (Assi and Guinko, 1991). The genus Piliostigma which is now identified as different from Bauhinia, consist of three species which are trees, evergreen small to medium and generally grow up to 10 metres high (Index Kewensis, 1953; Allen and Allen, 1981). 
The leaves are simple, broad deeply bilobed at the middle and the apex, typically Bauhinia-like, with 915 prominent main veins radiating from the base, at the point of attachment with the long petiole.

Piliostigma reticulatum is a shrubs or small trees 5-10m high having a bushy spherical canopy , with a trunk that is often twisted, and possessing a dark brown, fibrous and deeply longitudinally fissured outer bark and pink to red inner side of the bark. The leaves are bilobed (split in half in cattle hoof shape) and covered below by a reddish pubescence and are $7.5-16 \mathrm{~cm}$ long and $10-18 \mathrm{~cm}$ broad. The flowers are usually white and fragrant. The flowers are clustered in short hairy, axillary racemes $4-5 \mathrm{~cm}$. The petals of the flower are white with pink stripes, while the pods are woody, flat, straight, undiluted or twisted, hard, glabrous or sparsely pubescent, indehiscent and persisting, many - seeded, up to $25 \mathrm{~cm}$ long $\times 5 \mathrm{~cm}$ wide and dark brown when ripe (Adjanohoun et al., 1991; Assi and Guinko, 1991 and Vodouhe et al., 2010) . The plant fibre is strong; the wood is heavy and hard. The wood is liable to attacks by termites and borers. The wood is good source of fire wood, because it does not burn fast.

The local Nigerian names of $P$. reticulatum are Kargo (Or Kalgo) in Hausa (Northern Nigeria), Abafe in Yoruba language (Western Nigeria) and Okpo-atu in Igbo (Eastern Nigeria) (Dalziel, 1937; Burkill, 1995). Other common names include camel food (English); pied de chameau, semallier (France), Musacanca (Portugal) (Vodouhe et al., 2010). The plant is also known as Barkee - hi in fulfulde by Fulani in Nigeria (Roger and Mallam, 2006).

The members of the genus Piliostigma occur in tropical Africa and Indo-Malaya.The two African species $P$. reticulatum (DC.) Hochst and $P$. thonningii (schum.) milne - Redhead, inhibit dry and moist savannahs, respectively (Allen and Allen, 1981). $P$. reticulatum has close resemblance to $P$. thonningii to the extent that they can be easily confused with each other during identification, although at very close range distinguishing morphological features become apparent. $P$. reticulatum has smaller leaves and smoothness on the lower side where as $P$. thonningii has larger leaves and hairiness on the lower side. When they enjoys damp climate, they readily colonizes abandoned land (Burkill, 1995). The plant is semi-deciduous, losing most of its leaves at the end of the dry season, but in more humid zones the leaves are often persistent.

The plant re -sprouts after the stem has been cut. Animals eating the fruits assist in the plant seed dispersal. The plant grow from the sea level up $2000 \mathrm{~m}$ altitude in areas with an annual rainfall of $400-1000 \mathrm{~mm}$, mainly on heavy and poorly drained soils, but also on sandy soils. It is a pioneer species in woodland, wooded scrubland, wooded grassland, valleys and disturbed habitats such as cultivated fields, fallows and road sides. The species is common and locally abundant. The plant is propagated by seed. The seed germination can be improved by soaking the seed in hot water overnight (Vodouhe at al., 2010). The plant bark is harvested by cutting the branches and the bark removed when the cut branches are fresh. Mature fruits and young leaves are directly harvested from the plant for various uses.

$P$. reticulatum is used as a medicinal plant to treat various ailments throughout West Africa. The most common indications are cough, diarrhea and dysentery, fever, headache, toothache and wounds and ulcers. Most of these indications are related to inflammatory conditions or infections.Aderogba et al. (2006) confirmed the antimicrobial and antiinflammatory effects of Piliostigma reticulatum leaf extract by its comparison with that of Piliostigma thonningii. The antibacterial activity of cold aqueous, hot aqueous and ethanolic extracts of Piliostigma reticulatum showed that the ethanolic extract exhibited greater activity than both the cold and the hot aqueous extracts (Awe and Omojasola, 2009). The higher activity of the ethanolic extracts may not be unconnected with the extraction solvent because ethanol has been shown to be better solvent than water (Akinyemi et al., 2000). This may also account for the reason why the herbal physicians prefer to use local alcoholic decoctions in extracting the herbs rather than aqueous extracts in treating their patients. Jelili (2009) tested the antimicrobial activity of $P$. reticulatum leave extracts using different extracting solvents (hexane, ethylacetate, methanol and water) on some gram-positive and negative bacteria and fungi. The result indicated some level of activity on the tested organisms. The plant leaves are used to wrap foods. The stems are used as tooth brushes (Vodouhe et al., 2010).

Although there is limited information on the use of $P$. reticulatum seed as ingredients in livestock feed formulation. Akin-Osanaiye (2009) conducted a resaerch on the nutritional potentials of $P$. reticulatum with view of exploitation of plant seeds as an alternative plant protein source for human and livestock feed formulation.

Legumes are important sources of dietary protein for both human and animals, but the presence of relatively high concentration of toxins such as phytate, tannins and oxalate referred to antiantinutritive factors affects the nutritional quality by interacting with intestinal tract and also reduce protein digestibility and amino acids absorption (Nowacki, 1980). Liener (1994) reported that unless these substances are destroyed by heat or other processing methods, they can exert adverse physiological effects when ingested by human or animals.

Ghadge et al. (2008a) reported that legumes represent a major source of nutrients, including valuable but incompletely balance protein, particularly in vegetarians' diet. The nutritive value of legumes depends upon the processing methods, presence or absence of anti-nutritional or toxic factors and possible interaction of nutrients with other food components (Ghadge et al., 2008b).

Processing feedstuff make it safe for consumption. The factors that affect nutrients content resulting from feedstuff processing are; sensitivity of the nutrients to light, heat, oxygen (Morris et al., 2004). 
Bajopas Volume 8 Number 1June, 2015

The different ways of feed stuff processing may affect significantly the concentration and availability of minerals, vitamins and other essential compounds in the feedstuff. The nutritional value of a processed food is rarely better than that of the raw food, although there are some beneficial effects of processing (e.g the destruction of trypsin inhibitor in legumes and the liberation of bound niacian in cereals). During processing, nutrients are lost because they are leached by water at some stage in the processing

To improve the nutritional quality and to provide effective utilization of legumes for animal feed, it is important to establish a processing method (s) that will remove or reduce the anti-nutritional factors. Various processing methods have been used in legume seeds (Farran et al, 2001; Barbour et al., 2001). The aim of the study is to determine the processing method suitable for processing $P$. reticulatum seed for animal feed formulation

\section{MATERIAL AND METHOD}

\section{Seed Samples Collection and Identification}

Dry pods of Piliostigma reticulatum were obtained from Damfamin -Tofa, Ganduje Villages, of DawakinTofa local government area and new campus Bayero University Kano, all in Kano state. Kano is in the Sudan Savannah of Nigeria. It lies between latitude $11^{\circ} 30^{\prime \prime} \mathrm{N}$ and longitude $8^{\circ} 30^{\prime} \mathrm{E}$ and at an altitude of about $400 \mathrm{~m}$ above sea level(Olofin, 2008). The pods were treated using motor and pestle and winnowed on a tray by blowing air through to remove the chaff in order to have a clear seeds for the research.

The plant and the Pods Samples were identified at the herbarium of the department of biology, Ahmadu Bello University, (ABU) Zaria.

\section{Seed Processing}

The collected seed samples were divided into eight (8) portions and processed differently, a modification of Anwa et al. (2007) Method as follows-

Treatment one $(\mathrm{T} 1)=$ raw $P$. reticulatum seed (RPRS), Treatment two $(\mathrm{T} 2)=30$ minutes boiled $P$. reticulatum seed $\left(\mathrm{BPRS}_{30}\right)$ Treatment three $(\mathrm{T} 3)=60$ minute boiled $P$. reticulatum seed $\left(\mathrm{BPRS}_{60}\right)$, Treatment four $(\mathrm{T} 4)=$ traditionally boiled $P$. reticulatum Seed $\left(\mathrm{BPRS}_{\mathrm{T}}\right)$, Treatment five $(\mathrm{T} 5)=40$ minutes toasted $P$. reticulatum seed $\left(\right.$ TPRS $_{40}$ ), Treatment six $(\mathrm{T} 6)=80$ minutes toasted. $P$. reticulatum Seed $\left(\right.$ TPRS $\left._{80}\right)$, Treatment seven (T7) $=120$ minutes toasted $P$, reticulatum seed $\left(\right.$ TPRS $\left._{120}\right)$ and Treatment eight $(\mathrm{T} 8)=$ Traditionally roasted $P$. reticulatum Seed $\left(\mathrm{RPRS}_{\mathrm{T}}\right)$.

The raw $P$. reticulatum seed samples were boiled with clean bore hole water using one part of the raw seeds to ten (10) parts of the bore hole water $1: 10(\mathrm{~W} / \mathrm{V})$ at the ratio of $5 \mathrm{~kg}$ : 10 litres (Vadivel and Pugalanthi, 2007) in an aluminum pot of 15litres capacity on a stable flame gas cooker for the respective treatment periods that has to do with boiling. The water boiled at of $100^{\circ} \mathrm{C}$ before the seeds were poured into the pot. Time of the boiling was monitored using stop watch. Traditional boiling was carried out using bigger aluminum pot on fire wood as source of heat with excess water to seed ratio. The boiling was continued until the seeds were very soft to allow for hand de-hulling. Dense OXbrown exudates were observed during boiling and it became more pronounced as the duration of boiling increased. Toasting was done using an electric oven (DHG -9101 model) set at $75^{\circ} \mathrm{C}$ for each processing that had to do with toasting. Traditional roasting was done by constantly stirring the raw seed to prevent charring in a dry 5 minutes pre-heated open metal pan (traditionally made) using fire wood heat until browned

The boiled seed samples were spread and allowed to cool on clean trays, while the roasted and toasted seeds were exposed to air on trays in the laboratory to hasten cooling. The processing was carried out in the food Science and technology laboratory, Kano University of science and technology, Wudil. The processed seed samples were milled separately into a fine powdered form in the soil science laboratory faculty of agriculture, Bayero University Kano. The samples were than stored in air tight containers separately in a cool place pending chemical analysis.

\section{Proximate Analysis of the Experimental Seed} Proximate composition of the raw and differently processed seeds were carried out using AOAC (1990). The experimental design used was complete randomize design (CRD) and the treatments were in triplicates.

\section{Statistical Analysis}

The data generated during the seed chemical analysis was analysed using one-way analysis of variance (ANOVA) and the differences among the means were tested for significance using Duncan Multiple Range Test (Duncan, 1955) at 95\% level of probability. The statistical packages used were SAS package (SAS, version, 9, 2002) SAS Institute Inc. Cary. NC. USA

\section{RESULTS}

The proximate composition of raw and differentially heat processed $P$. reticulatum Seed Meal (DHPPRSM)

\section{Moisture Content}

The results presented in Table 1 showed that the raw seed sample had $7.27 \%$ moisture content. While the moisture content of the differentially heat processed $P$. reticulum seed meal (DHPPRSM) decreased significantly $(P<0.05)$ from the raw seed value with exception of T2 (30 minutes boiled), T4 (Traditionally boiled) and also T7 (120 minutes toasted) which significantly increased.The moisture content in this work ranged from 1.91 for T5 (40 minutes toasted) to 10.24 for T7 (120 minutes toasted). 
Bajopas Volume 8 Number 1June, 2015

\section{Crude Protein (CP) Content}

The crude protein (CP) of the DHPPRSM decreases with increased period of heat treatment. T2 (30 minutes boiled) showed the highest $\mathrm{CP}$ value of (36.01\%) and T6 (80 minutes toasted) have the least $\mathrm{CP}$ value of $20.96 \%$ ) in the differently heat processed $P$. retriculatum seed. There was significance difference $(P<0.05)$ between the raw seeds and the DHPPRSM. Among the DHPPRSM, T3 (60 minutes boiled), T5 (40 minutes toasted) and T8 (Traditionally roasted) seeds showed no significant difference $(P>0.05)$ (Table 1$)$.

\section{Crude Fibre Content (CF)}

The crude fiber of the differently heat processed seed decreased with increase of heat treatment period more especially in the moist heat treatment. Among the heat processed seed T5 (40 minutes toasted) had the highest CF value of $5.29 \%$. T8 (Traditionally roasted) seed recorded the least crude fiber content of $2.60 \%$ followed by T4 (Traditionally boiled) with value of $3.09 \%$ There was no significant difference ( $P>0.05)$ between T3, T4, andT7 and also between T5 and T6 in the processed seed (Table 1).

\section{Crude Ether Extract (EE)}

The ether extract content of the differently heat processed seed increases with increase period of heat treatment. The result showed significant difference $(P<0.05)$ between the raw and the heat processed seed. Among the processed seed T3and T8 and also T6and T7 showed no significant difference at $(P>0.05)$ (Table 1$)$.

\section{Ash Content}

The ash content of the differently heat processed seed increased with the increased of processing time (Table 1$)$. There was significant difference $(P<0.05)$ between the raw and the processed seed. Among the processed seed, there was significant difference $(P<0.05)$ within the boiled seed and also in the dry heat treatment, except in T5 (40minutes toasted) and T8 (Traditionally roasted) and also T2 and T6 (Table 1).

\section{Nitrogen Free Extract (NFE)}

The nitrogen free extract (NFE) decreased with the increase of heat treatment period, except in T6 and T7 (Table 1) (which were in dry heat treatment). There was significant difference $(P<0.05)$ between the raw and the processed seeds, with exception of T2 and T4 (Table 1), the differently processed seed showed significant difference at $(P<0.05)$ (Table 1$)$.

Table 1: Proximate Composition of the Raw and Differently Processed Piliostigma reticulatum Seed Meal (\%)

\begin{tabular}{|c|c|c|c|c|c|c|c|c|c|}
\hline \multirow[b]{2}{*}{$\begin{array}{l}\text { Proximate } \\
\text { compositio } \\
\text { n (\%) }\end{array}$} & \multicolumn{6}{|c|}{ TREATMENT } & \multirow[b]{2}{*}{$\begin{array}{l}\text { T7 } \\
120 \mathrm{mins} \\
\dot{\text { Toasted }}\end{array}$} & \multirow[b]{2}{*}{$\begin{array}{l}\text { T8 } \\
\text { TRAD } \\
\text { Roaste } \\
\text { d }\end{array}$} & \multirow[b]{2}{*}{ MSE } \\
\hline & $\begin{array}{l}\text { T1 } \\
\text { Raw } \\
\text { Seed }\end{array}$ & $\begin{array}{l}\text { T2 } \\
30 \mathrm{mins} \\
\text { Boiled }\end{array}$ & $\begin{array}{l}\text { T3 } \\
60 \mathrm{mins} \\
\text { Boiled }\end{array}$ & $\begin{array}{l}\text { T4 } \\
\text { TRAD } \\
\text { Boiled }\end{array}$ & $\begin{array}{l}\text { T5 } \\
40 \mathrm{mins} \\
\text { Toaste } \\
\text { d }\end{array}$ & $\begin{array}{l}\text { T6 } \\
80 \mathrm{mins} \\
\text { Toaste } \\
\text { d }\end{array}$ & & & \\
\hline Moisture & $7.27^{b}$ & $7.26^{\mathrm{b}}$ & $6.25^{c}$ & $7.07^{b}$ & $1.91^{f}$ & $5.16^{d}$ & $10.24^{\mathrm{a}}$ & $3.20^{\mathrm{e}}$ & 0.3658 \\
\hline $\begin{array}{l}\text { Crude } \\
\text { protein }(\mathrm{CP})\end{array}$ & $34.20^{\mathrm{b}}$ & $36.01^{a}$ & $31.54^{c}$ & $28.48^{\mathrm{d}}$ & $31.94^{c}$ & $20.96^{f}$ & $24.12^{\mathrm{e}}$ & $31.37^{c}$ & 0.4962 \\
\hline $\begin{array}{l}\text { Crude fiber } \\
\text { (CF) }\end{array}$ & $6.05^{\mathrm{a}}$ & $4.71^{c}$ & $3.33^{d}$ & $3.09^{d}$ & $5.29^{b}$ & $5.24^{b}$ & $3.42^{d}$ & $2.60^{\mathrm{e}}$ & 0.2595 \\
\hline $\begin{array}{l}\text { Crude ether } \\
\text { extract (EE) }\end{array}$ & $5.51^{f}$ & $7.10^{\mathrm{e}}$ & $8.22^{d}$ & $12.89^{\mathrm{a}}$ & $11.21^{\mathrm{b}}$ & $9.04^{c}$ & $9.03^{c}$ & $8.15^{d}$ & 0.1400 \\
\hline Ash content & $7.21^{\mathrm{e}}$ & $8.09^{d}$ & $14.01^{\mathrm{a}}$ & $11.76^{\mathrm{c}}$ & $13.02^{\mathrm{b}}$ & $8.74^{\mathrm{d}}$ & $11.27^{\mathrm{c}}$ & $12.91^{\mathrm{b}}$ & 0.4883 \\
\hline $\begin{array}{l}\text { Nitrogen free } \\
\text { extract (NFE) }\end{array}$ & $47.03^{C}$ & $44.08^{d}$ & $42.90^{e}$ & $43.78^{d}$ & $38.62^{f}$ & $55.69^{a}$ & $52.16^{\mathrm{b}}$ & $44.20^{d}$ & 0.9499 \\
\hline
\end{tabular}

Means with the same letter within a row are not significantly different with DMRT at $5 \%$ level of probability. TRAD = Traditionally

\section{DISCUSSION}

The result of moisture content of the raw seed sample recorded in this work $(7.27 \%)$ was higher compared to $2.70 \%$ reported by Akin- Osanaiye et al. (2009) for the same plant.Jimoh and Oladiji (2005) recorded similar result $(6.71 \%)$ of the same plant genus ( $P$. thonningii) raw seeds.

Generally, heat treatment was found to decrease the moisture content of the seed in this study. This observation was in agreement with the finding of Anwa et al. (2007) using Albizzia lebbeck seeds. The moisture variation within the sample treatments could be due to processing techniques and experimental errors.

The moisture of the raw and processed seed were generally low and the recorded values fall below $15 \%$ moisture content required as safe storage limit for plant feed stuff (Sena et al., 1998). This shows that the seeds could be stored for a long period of time without growing mould or lowering their quality (Abubakar, 2007).

The $\mathrm{CP}$ content recorded in the raw seed (34.20\%) in this study is in accordance of $(30.3 \%)$ recorded by Akin- Osanaiye et al. (2009) using raw undefatted seeds of the same plant species. Jimoh and Oladiji (2005) also reported similar value of $(30.33 \%)$ for the same plant genus ( $P$. thonningil) raw seed. However, Akin- Osanaiye et al. (2009) reported the value of $(40.4 \% \mathrm{CP})$ in the defatted seed of $P$. reticulatum. 
Bajopas Volume 8 Number 1June, 2015

The CP content of DHPPRSM generally decreased with the increased period of heat treatment. Iorgyer et al. (2009) reported similar result of decrease in CP with increase of heat treatment period using pigeon pea seeds and this could be due to leaching of soluble or proteineous parts of the seed into the boiling water. Balogun (2011) reported that the values of $\mathrm{CP}, \mathrm{CF}, \mathrm{EE}$, Ash, NFE and EAAI reduces with increase in heat treatment period (boiling) which is accordance with the findings in this study. Nsa et al. (2011) observed that decrease in CP of castor oil seed, as boiling and soaking duration increased could be attributed to some solubilization and leaching out of nitrogenous substances into the water. This accounts for the longer duration of boiling and soaking, the more the lost of CP. This statement explains the lower value of $28.48 \%$ for T4 (Traditionally boiled) which took longer duration of boiling in moist heat treatment of this study when compared with the other values of moist heat treatments (Table 1). Another study on Isoberlinia doka seeds by Gwani (2009) showed similar reduction pattern in $\mathrm{CP}$ content with increased of boiling period. The decreased of CP content may be attributed to denaturization of protein with increase in temperature above $37^{\circ} \mathrm{C}$ as reported by $\mathrm{Abu}$ et al. (2005) and Gwani (2009) on Lima bean and Isoberlinia doka seeds respectively.

Nsa et al. (2011) reported deffernt finding in crude protein content of castor oil seeds using moist heat treatment. It has also been reported that heating damages protein, due to the destruction of lysine and that of all the proteins used to feed animals, (Livestock and fish) only soybean products appears to improved by heating (NRC, 1993). The high CP content $(36.01 \%)$ recorded in T2 (30 minutes boiled) in this work could be attributed to the destruction of heat - labile anti-nutrients or toxic compounds in the early heat treatment (boiling) of the seed. It has been reported that early in the cooking/boiling process there is loss of toxic activity, particularly of the proteinaceous toxins, trypsing inhibitors and heamagglutinin (Liener, 1980). As heating proceeds, protein quality increases to a maximum before declining again with continued heating; thus reduction is likely to be related to increasing maillard browning causing lysine to be rendered unavailable (Aremu et al., 2010).

For a feedstuff to be regarded as a potential protein source, its crude protein level must exceed 20\% (Auta and Anwa, 2007). This therefore means that $P$. reticulatum seed is a protein source.

There was reduction of crude fiber (CF) content of the heat treated seed as the duration of the treatment increased in this study. Nsa et al. (2011) reported non significant reduction in CF content of castor oil seed with increasing boiling time.

The crude fiber content of the raw and the differently heat treated seeds were $(6.05 \%)$ and range of $2.60 \%-5.29$ (Table 1 ) respectively. Higher values were recorded by Anwa et al. (2007) for both raw and heat processed (boiled, toasted and roasted) Albizzia lebbeek seed. Balogun, (2011) recorded similar crude fiber value $(6.41 \%)$ in the raw seed of
B. monandra, but higher values in the heat treated (toasted) seed $(8.83-9.07 \%)$ as compared to this study heat treated seed values range of (2.60 $5.29 \%)$. Crude fibre content of the related plant genus ( $P$. thonningii) raw seed was $35.03 \%$ as reported by Jimoh and Oladiji (2005) which was higher than this work raw seed crude fibre.

The reduction in crude fibre might be due to dehulling during processing or/and removal of some water - soluble oligosaccharides such as the raffinose families and the indigestible carbohydrate during boiling processes (Gashaw, 2010).

The recorded crude fibre values for this study are within the recommended maximum level of $8 \%$ crude fibre for fish diet (Dupree and Huner, 1984) therefore, in this study the crude fibre content assisted in the chosen of the best heat treatment method. Treatment T4 (Traditionally boiled) and T8 (Traditionally roasted) had the least fibre content (3.09\% and $2.60 \%)$ respectively, but disadvantaged in terms of protein quality (Table 1 )

Akin- Osanaiye et al. (2009) reported higher value $(27.9 \%)$ of EE than the value $(5.51 \%)$ recorded in this study for the same plant species raw seeds. The values $(5.51 \%)$ and $(7.10-12.89 \%)$ recorded for the raw and heat processed seeds in this study, were lower than the values $(20.72 \%)$ and (18.44 - $19.73 \%)$ reported by Nsa et al. (2011) on heat treated (boiled) castor oil seed respectively. However, Jimoh and Oladiji (2005) recorded lower value $(1.42 \%)$ in the raw seeds of related plant genus ( $P$. thonningii). These variations might be due to differences in species, processing techniques or geographical locations.

There was general increased in the EE content as the heat processing period increased in this study.

Feedstuffs with high fat content are prone to oxidative rancidity due to the effect of long time storage (UNDP, 1983; Sena and Anderson 1995, Effiong and Eyo, 1997). Rancid fats reduce palatability and therefore reduce availability of nutrients to fish (Rumsey, 1980) and can contain toxic compounds which inhibit growth. Haruna (1997) indicated that $8-10 \%$ lipid contents, in fish (C. gariepinus) formulated diet produced best growth.

The trend of increase with heat processing shown by ash content in this work was with the accordance of Effiong and Umoren (2011) findings, that reported processing (soaking, followed by cooking and toasting) significantly $(P<0.05)$ increase the level of ash from $3.28 \%$ in the raw horse eye beans to $4.98 \%$ in $72 \mathrm{~h}$ soaked, $90 \mathrm{~min}$ cooked and then toasted seeds. This increased in ash content might be due to the destruction of the anti-nutritional factors, especially phytates which are thought to be responsible in mineral bio-availability (Osman, 2007).

The value $(4.0 \%)$ of ash content reported by Akin-Osanaiye et al. (2009) was low compared to the value $(7.21 \%)$ recorded in the present study for the raw seed of the same plant species. This variation might be due to the differences in the processing techniques and geographical location. 
The NFE value of the raw seed $(47.03 \%)$ recorded in this study, was low compared to the value of (65.26\%) reported by Gashaw (2010) of the raw grass pea, but higher then the value of (25.0\%) and (23.0\%) reported by Akin- Osanaiye et al. (2009) and Jimoh and Oladiji (2005) of $P$. reticulatum and $P$. thonningii raw seeds respectively.

In the present study, the NFE reduces with increase in processing time. This agreed with the finding of Balogun (2011) on boiled Bauhinia seed that reported reduction of NFE with increase of boiling time. Similar trend of NFE reduction with increase of heat processing on $B$. monandra seed was reported by Agbugui et al. (2010). The reduction of NFE during moist heat treatment might be due to leaching of soluble carbohydrates like sugars into the boiling water (Esenwah and Ikenebomeh, 2008; Gashaw, 2010).

Generally the result of this study showed significant difference $(P<0.05)$ between the raw

\section{REFERENCES}

Abu, A.E., Anigo, K.M., Chindo, S.P., James, D.B. and Yakubu, L.B. (2005). Evaluation of some traditional processing methods on the nutrient composition and in vitro protein digestibility of Lima bean (Phaseolus Iunatus). Nigerian Journal of Scientific Research 5 (1): $65-67$.

Abubakar, A.S. (2007). Biochemical Analysis of Four Legumes in Zaria. MSc Thesis Post Graduate School. ABU Zaria 69 Pp.

Aderogba M.A., Okoh, E.K., Okek, I.N., Olagide, A.O., Ogundaini, A.O. (2006). Antimicrobial and Anti-inflammatory effects of Piliostigma reticualtum leaf extract. Int. Journal of Pharmacology 2 (1), $70-74$.

Adjanohun, E., Ahiyi, M.R.A., Assi, L.A., Dramane, K., Elewude, J.A., Fadoju, S.O., Gbile, Z.O., Goudote, E., Johnson, C.L.A., Keita, A., Morakinyo, O., Ojewole, J.A. and Sofowora, E.A. (1991). Traditional medicine and pharmacopoeia: contribution to ethnobotanical and floristic studies in Western Nigeria. Organization of African Unity/Scientific Technical and Research Commission 93 337, 343 and 354.

Agbugui, M., Oniye, S.J. and Auta, J. (2010). Effects of processing on the mineral content, proximate composition and phytochemical factors of the seed of Bauhinia monandra (KURZ) Bayero Journal of Pure and Applied Sciences, 3 (1): $23-25$.

Akin-Osanaiye, B.C., Agbaji, A.S. and Abdulkadir, O.M. (2009). Proximate composition and the functional properties of defatted seed and protein Isolates of Kargo ( $P$. reticulatum) seed. AJFAND Online Vol. 9 No. 6 Pp 1365 $-1377$.

Akinyemi, K.O., Coker, A.O., Bayagbon, C., Oyefolu, A.O.B., Akinside, K.A. and Ominigbehin, E.O. (2000). Antibacterial Screening of Five Nigerian Medicinal Plants against $S$. typhi and Paratyphi. Journal of Nigerian Infection Control Association 3 (1). and differently processed seed in nutrients content. Similar result was reported by Saulawa et al. (2014) on Baobab seed. Significance differences were observed between some of the differently processed seed in this study. Saulawa et al. (2014) reported similar result on Baobab seed.

In the proximate composition analysis (Table 1) T2 (30 minutes boiled seed) had the highest CP content (36.01\%), but have disadvantage when compared with the second group (T3, T5 and T8) in the other parameters of the analysis with exception NFE (Table 1).

Amongst the second group (T3, T5 and T8), T3 advantaged the others in terms of moderate CP and NFE and also had the highest ash content. T1 (raw seed), although have high CP (34\%), but have the highest CF and the lowest ash content. Thus from this finding of this study, T3 (60 minutes boiled) appeared to be the best in terms of proximate composition for animal feed formulation.

Allen, O.N. and Allen, E.K. (1981). The leguminosae: A source Book of characteristics, uses and Nodulation. The University of Wisconsin Press, USA. Xii - xxiii: 52.

Anwa, E.P., Auta, J. Abdullahi, S.A. and Bolorunduro P.I. (2007). Effects of Processing on Seeds of Albizzia lebbeck. Proximate Analysis and Phytochemical Screening. ResearchJournal of Biological Sciences 2(1): 41-44

Aremu, M.O., Olaofe, O., Basu, S.K., Abdulazeez, G. and Acharya, S.N. (2010). Processed cranberry bean (Phaseolus coccineus $\mathrm{L}$ ) seed flour African diet. Can. J. Plant Sci. 90: $719-728$.

Assi, L.A. and Guiniko, S. (1991). Plants used in traditional medicine in West Africa. Swiss Centre for Scientific Research in Ivory cost. And Roche Africa Research Foundation. 17$18,56$.

Auta, J. and Anwa, E.P. (2007). Preliminary studies on Albizzia lebbeck seeds: Proximate Analysis and Phytochemical screening. Research Journal of Biological Sciences 2 (1): $33-35$.

Awe, S. and Omojasola, P.F. (2009). A Comparative Study of the Antibacterial Activity of Piliostigma reticulatum Bark Extract with some Antibiotics. Ethnobotanical Leaflets 13: $1197-1204$.

Balogun B.I. (2011): Growth Performance and Feed Utilization of Clarias gariepinus (Teugels ) Fed Different Dietary Levels of Soaked Bauhinia monandra (Linn) Seed Meal and Sun-dried Locust Meal (Schistocerca gregaria ) Ph.D Thesis Postgraduate School Ahmadu Bello University, Zaria 184pp

Barbour, E.K., M. Kallas and M.T. Farran (2001). Immume response to Newcastle disease virus in broilers: A useful model for the assessment of detoxification of ervil seeds. Rev. Sci. Tech. Off...Int. EP. Z,20: 785 -790.

Burkill, H.M. (1995). The useful plants of West Tropical Africa. Edition 2, Volume 3, Families J-L. Royal Botanic Gardens, Kew. 144-150. 
Dalziel, J.M. (1937). The useful plants of West Tropical Africa. Grown agents, London. 174 $-175$.

Duncan, D.B. (1955). Multiple range and multiple Ftest. Biometrics. $11,1-42$.

Dupree, H.K. and Huner, J.V. (1984). Third report to the fish farmers. The status of warm water fish farming and progress in fish farming research. U.S. Dept. of the Interior Fish and Wildlife Services, Washington D.C. 270pp..

Effiong, B.N. and Eyo, A.A. (1997). Control of mould infestation in stored pelleted feeds. NIFFR. Annual Report Pp 1288 - 134.

Effiong, O.O. and Umoren U.E. (2011). Effect of Multi-processing techniques on the chemical composition of Horse Eye bean (Mucuna urens) Asian Journal of Animal Scuences, 5: $340-348$.

Esenwah, C.N. and Ikenebomeh, M.J. (2008). Processing Effects on the Nutritional and Anti-Nutritional contents of African Locust Bean (Parkia biglobosa Benth) seed. Pakistan Journal of Nutrition, 7 (2): 214 217.

Farran, M.T., P.3 Dakessian, A.H. darwish, M.G. uwayjan, H.G Dbouk, F.T, Seliman \& V.M Ashkarin. (2001). Performance of broilers production and egg quality parameters of laying hens fed $60 \%$ raw and treated common vetch (Vicia ervilia) seeds. Poult Sci., 80:203-208.

FOA, (1994). The state of food and agriculture, POA, agricultural services 27, FAO/UN, Roma.

Gashaw, G. (2010). Effects of Traditional Food Processing Methods on Nutrient Compositions and Anti-nutritional Factors of Grass Pea (Lathyrus sativus L) Foods consumed, in Ethiopia. Published M.SC. Thesis Graduate Studies Program, Addis Ababa University, Ethiopia. 69Pp.

Ggadge, P.N., Vairagar, P.R. and Prasad, K. (2008a) physical properties of chick pea split (Cicer arietenum L.). Agricultural Engineering International: The CIGR Ejournal. Manuscript FP 07039. Vol. X.

Ghadge, P.N., Shewalkar and Wankhede, D.B. (2008b). Effect of processing methods on qualities of instant whole legumes: pigeon pea (Cajanus cajan L.). Agricultural Engineering International: The CIGR Ejournal. Manuscript FP 004 Vol. X.

Gwani, H.T. (2009). The Effect of Isoberlinia doka (Craib and stape) seed meal on the Growth performance and Carcas characteristics of Rabbits. M.Sc. Thesis Postgraduate School, ABU Zaria. $71 \mathrm{Pp}$.

Haruna, A.B. (1997). Studies on the utilization of Agro and agro-allied wastes in the nutrition of the African catfish, Clarias gariepinus Burchell, 1822; Ph.D Thesis, BUK 187 pp.

Index Kewensis (1953). Supplementum XI (19411950) 188.

Iorgyer, M.I., Adeka, I.A., Ikondo, N.D. and Okoh, J.J. (2009). The Impact of Boiling periods on the proximate composition and level of some anti-nutritional factors in pigeon pea. (Cajanus cajan) seeds. PAT 2009; 5 (1): 92 - 102 ISSN; $0794-5213$

Jelili, O.B. (2009). Chemical and Biological Investigation into some selected African Indigenous Medicinal Plants. Published Ph.D Thesis, Department of Chemistry, University of the Western Cape.

Jimoh, F.O. and Oladiji, A.T. (2005) Preliminary Studies on Piliostigma thonningii Seeds: Proximate analysis, mineral composition and pytochemicalscreening. African Journal of Biotechnology, 4: (12) PP 1439- 1442.

Liener, I.E. (1994). Implications of antinutritional components in soybean foods. Critical Review of Food Science and Nutrition 34: 31 $-67$.

Liener, I.E. (ed.), (1980). Toxic constituents of plant stuffs. $2^{\text {nd }}$ edn. Academic Press, New York, NY.

Michaelson, K.F and F. Henrik, (1998). Complimentary feeding, a global perspective. Nutria, 14: 763-766.

Morris, A., Barmelt, A and Burrows, O.J (2004). Effect of mocersing on nutrient content of foods. Cajarticles, 37 (3): 160-164.

National Research Council (NRC). 1993. Nutrient requirement of fish. National Academy press, Washington. DC 114pp.

Nowacki, K, (1980). Heat stable anti-nutritional factors in leguminous plants. Summefield, R,J, Buntong, A.H, (ed). Advances in legume science, Kew. Royal Botanical Gerdens, pp 171 - 177.

Nsa, E.E., Ukachukwu, S.N., Isika, M.A. and Ozung, P.O. (2011). Effect of Boiling Soaking Durations on the Proximate Composition, Ricin and Mineral Contents of Undecoticated Castor oil seeds (Ricinus communis) International Journal of Plant, Animal and Environmental Science Vol. 1, Issue - 3 ISSN 2231 - 4490.

Olofin, E.A.(2008).general introduction In: E.A Olofin, A.B. Nabegu and A.M.Dambazau (eds). Wudil within Kano region, $A$ geographical synthesis. Adamu Joji publishers Kano city, Kano. Pp 1-4

Osman, M.A. (2007). Effect of different processing methods on nutrients composition, antinutritional factors and in vitro protein digestibility of Dolichos Lablab bean (Lablab purpuresus ( $\mathrm{L}$ ) sweet ). Pakistan Journal of Nutrition 6: 299 - 303.

Pellelier, D.L. (1994). The potentiating effects of malnutrition on child mortality. Epidemiological evidence and policy implications. Nutria Rev., 52: 409-415.

Roger, B. and Mallam, D. (2006). Fulfulde names for plants and trees in Nigeria, Cameroun, Chad and Niger. Cambridge CBI 2AC U.K

Rumseey, G.L. (1980). Stability of micro-nutrients in fish feed in: Fish feed technology chap. 14 PP 225 - 229. Washington 1978. 
Saulawa L.A., A.I. Yaraduwa and L. Shuaibu (2015) Effect of Different Processing Methods on Proximate, Mineral and Anti Nutritional Factors Content of Baobab (Adansonia digitata) Seed. Pakistan Journal of Nutrition 13 (6) 314-318.

Sena, L.P., Vanderjagt, D.J., Rivera, C., Tsin, A.T., Mahammadu, O., Millson, M., Pastuszyn, A. and Glew, R.H. (1998). Plant Food for Human Nutrition 52 (1) 17 - 30.

Sena, S.S. and Anderson, T.A. (1995). Fish Nutrition in Aquaculture. Champion and Hall Aquaculture series, first edition, champman and Hall, 2-6 Boundary Row, London SE 118 $-\mathrm{HN}$.

UNDP (1983). Fish Feeds in Developing Countries An Interim Report on the ADCP Feed Developing Programme, Aquaculture Development and Coordination Programmes ADCP/REP/8318. 96 Pp.
Vadivel, V. and Pugalenthi, M. (2007). Biological value and protein quality of raw and processed seeds of Mucuna pruriens var. utilis. Livestock Research for Rural Development 19 (7) 11pp.

Vodouhe, F.G., Ndanikou, S. and Achigan-Dako, E.G. (2010). Piliostigma reticulatum (DC.) Hoechst. In: Brink, M. and Achigan-Dako, E.G. (Editors). Prota 16: Fibres/plantes a fibres. (CD-Rom). PROTA, Wageningen, Netherlands. 